\title{
Gerhard Riemann
}

Technische Hochschule Nuremberg Georg Simon Ohm, Germany

\section{A Situation, a Narrative, and a Life History. The Case of Natalia}

DOI: https://doi.org/10.18778/1733-8077.10.1.02

Abstract I will first focus on problems which might emerge in narrative interviews with people who have experienced long-term trajectories of suffering, before discussing the researcher's specific style of doing this particular biographical interview - a style which is marked by sensibility and considerateness, but might contain some problems nevertheless. Afterwards, will deal with two formal features of the interviewee's introductory narrative - a complicated background construction and an extended pre-coda commentary - in order to revea the analytical significance of these features for a deeper understanding of the interviewee's life history and her way of making sense of her experiences. The article ends with a discussion of some topics which are relevant for an analytical abstraction.

Keywords Biographical Analysis; Autobiographical Narrative; Trajectories of Suffering; Background Construction; Pre-coda Commentary

\section{The Idea}

So-called "data sessions," in which researchers jointly analyze primary materials, like interview transcriptions, field notes, and other data, have turned out to be very valuable events in many conferences in biographical research and other approaches to

Gerhard Riemann, is a sociologist and a professor of Social Work at the Technische Hochschule Georg Simon Ohm in Nuremberg. His main research interests are biographical research, narrative analysis, and the analysis of professional work

\section{email address:}

gerhard.riemann@th-nuernberg.de qualitative analysis - valuable because colleagues make their specific ways of looking at things visible to each of them and thereby reveal a lot of the analytical processes of discovery, which usually stay hidden in standard presentations of results. The atmosphere of such working sessions is of ten surprisingly cooperative; people often forgo the habitual tendency to celebrate the putative strengths of their own approach while creating a simplified or even stereotypical image of the other persons' pitiable ways of understanding their data. Sometimes, such "data sessions" lead to publications which invite readers to critically assess the articles on the basis of their own reading of the data which are accessible to them. Two examples are the collection of analyses of an autobiographi- cal narrative interview with a female Turkish migrant laborer in Germany (see: Riemann 2003) and (recently) the collection of analyses of the written life history of an Apache Indian (see: Bartelt and Treichel 2012).

When Agnieszka Golczyńska-Grondas ${ }^{1}$ made the English translation of the transcription of one of her interviews from her research project ${ }^{2}$ available, she joined this series of "data sessions" and subsequent publications. I welcome the chance to share with readers some of my observations and ideas about this impressive interview with a Polish woman who the researcher calls Natalia. I also appreciate Agnieszka's extraordinary openness to make an interview available, which she describes as the most difficult biographical interview I have ever conducted due to the narrator's very strong emotions and symptoms of suffering. ${ }^{3}$

I would like to show how I understand the interview situation, how I go about analyzing the text, and what I hope to have learned about Natalia. I will also allude to some insights which go beyond the particularities of the specific data. My own approach of doing biographical research and of analyzing narrative interviews - both autobiographical interviews and interviews on the development of relationships between professionals and clients (Riemann 1987; 2000) - has been shaped by the Hereafter, I refer to her as "Agnieszka," "the researcher," or "the interviewer."

The title of the project is Institutionalized identity? The processes of identity development on the basis of biographies rendered by adults raised in residential child care homes.

All quotations in italics are derived from the introduction to the interview with Natalia, which Kaja Kazmierska and Agnieszka Golczyhiska-Grondas sent to the authors of the rticles who are included in this special issue of Qualitative Sociology Review. work of Fritz Schütze (1987; 2008a; 2008b; SchröderWildhagen and Schütze 2011) and my long-term collaboration with him.

Putting the Interview with Natalia in Perspective

Agnieszka wrote in her first commentary on the interview which she had conducted with Natalia:

[o]ne of the basic intentions in face to face contact with the interviewees was to establish the narrator's sense of comfort and security in telling the life story abundant in traumatic memories from childhood, adolescence (and sometimes adulthood) - I purposely made a methodological assumption that in the project I would obtain two types of data - the narrative interviews and the in-depth biographical interviews. Thus, at the beginning of every interview, I asked all interviewees if they preferred to tell their life story or if they preferred to be asked questions.

I want to use this remark for a first reflection about the data.

Many qualitative researchers have been doing biographical studies on people who have presumably experienced deep and long-term trajectories of suffering (Riemann and Schütze 1991; Schütze 1992; 1995) - vulnerable people or even survivors of something which is difficult to survive. "Survivors" is an ambiguous term and is often used indiscriminately. If one thinks of biographical research, quite diverse studies come to mind. An extreme example is, of course, the experience of surviving collective man-made disasters, like wars and genocides (Rosenthal 1997; Kazmierska ${ }^{4}$ A recent publication based on this approach to analysis is
Miller and Day (2012). 
2002; 2012). In planning such studies, researchers often have to ask themselves if such a project might entail too many risks: Do people, who have experienced traumatic events of loss, betrayal, and deep physical and mental harm, and are asked to tell their lives, run the risk that such experiences are reawakened in the process of autobiographical story telling? Could they be overwhelmed by certain memories which had been "faded out" of awareness (Schütze 1992)? What about a situation which cannot be handled by the researcher anymore? But, researchers have also learned that people who have experienced long-term trajectories of suffering might be open, and even eager, to tell their story to a stranger who is genuinely interested. There might be no other people around with whom they could share their experiences: family members or friends might have numbed themselves to "these same old stories," or it could appear too risky to reveal shameful secrets to a spouse or child who might be shocked (one finds an example in the interview with Natalia) or to confide something to a friend who might start gossiping about "me."

People who do biographical research on people who they assume to have experienced deep trouble and long-lasting trajectories of suffering deal with such problems in different ways, but in any case, they need to make sensible decisions - whether or not it is responsible to conduct a narrative interview at all and who should do the interviewing - when, how, and where. All of this becomes important: the biographical phase of the prospective interviewee, the features of the interview situation, the biography and sensibilities of the interviewer/ researcher, and the style of the interviewing. Of course, such considerations are necessary for any kind of narrative interview but they appear especially urgent when thinking about people who are presumably especially vulnerable in specific ways.

Thinking about my own biographical research experience and the experience of students of social work whose research (based on autobiographical narrative interviews) I have supervised, I have found it helpful to keep the following points in mind:

- People might be reluctant to be interviewed and might allude to experiences which they don't want to talk about. Researchers should abstain from any kind of pressure or manipulation in securing prospective interviewees' cooperation - like making empty promises that it would be beneficial for them to look back and tell their life history. Autobiographical story telling is indeed often experienced as a relief or even as liberating (something which I discovered in my research on mental patients' biographies [Riemann 1987]), but social scientists should not predict and promise such "effects." During the interview, researchers have to respect interviewees' self-censorship and their allusions that they want to avoid certain topics.

- Researchers need to think carefully about features of the interview situation in order to secure a genuinely safe space for the interviewee - a space in which she or he can talk openly without risking damaging consequences. When thinking about a safe space, I have in mind, for example, that it is also necessary to keep a sufficient distance from possible spokespersons or gatekeepers who control the access to presumably "vulnerable" people who they want - or claim - to protect against outsiders and troublemakers (like researchers). Researchers might also run the risk of stirring up too much, for example, when interviewing members of the same group or family for the purpose of triangulating data and perspectives - thereby, arousing the curiosity of single interviewees in "What did she/he (my family member/friend, etc.) say about me?" [Therefore, I feel uneasy with certain types of biographical family research.]

- Researchers must not reduce the prospective interviewee to her or his membership in a certain (possibly stigmatized) category. People who have had a long career as patients or clients of powerful institutions have often learned to refer to - and think of - themselves by adopting the diagnoses and categories as a matter of course which have been ascribed to them by professionals and institutions of people processing. Oftentimes, they find it difficult to imagine that something else than "it" ("my" membership in a certain category: "my" being "psychotic," an "ex-prisoner," a "chronic patient," etc.) might interest a researcher. Researchers need to communicate that they are interested in much more than "it," for instance, that they want to learn about the whole life history - "how everything developed step by step."

- I find it important to keep a distance between the communicative style of doing narrative interviews in the world of research and the communicative style of doing therapy ${ }^{5}$ without overlooking the many practical uses of narrative interviewing, for example, in biographical counseling (Betts et al. 2008). During my research on mental patients' biographies (Riemann 1987), I conducted narrative interviews with them by refraining from any incorporation of therapeutic elements, like "mirroring." I assumed - and I still do - that such elements might lead to a confusion about the relationships and expectations which are difficult to fulfill in a research relationship - we are talking to our interviewees, who do us a favor by cooperating in a research project, and not our clients or patients.

People who had agreed to be interviewed in a narrative interview sometimes still hesitate in the situation when they are asked to tell their life history and express a preference for being asked a series of questions. Telling one's full life history is not the most common thing in the world. [When sitting together with other people in a pub or in a train, persons usually share bits and pieces but not their complete life history.] If interviewees are reluctant in the beginning, I tell them that I would help them along if things get difficult - trusting in the constraints of storytelling (Schütze 2008a; 2008b) as soon as they have started their narration, a trust which is usually justified. I prefer coherent narrations - or (depending on the research problem) other data which are dominated by a single scheme of communication (narration, description, argumentation) which can freely unfold (Kallmeyer and Schütze 1977) since the sequential analysis of

$\overline{{ }^{5} \text { I am aware that there are other colleagues in biographical }}$ research who do not share this position (Rosenthal 2005:150-
152). This issue should become a topic of further discourse. 
such a text can proceed on a firmer ground than the analysis of a text in which different schemes of communication confound each other (something which Fritz Schütze refers to as "schema salad" [1987:256]).

Agnieszka decided to follow a different path, and, of course, there are good reasons for her to do so. She told the interviewee (Natalia) that she could choose between an in-depth biographical interview (consisting of a series of questions) and a narrative interview. As she wrote: Natalia opted to follow my questions. I will turn to her style of interviewing and the dynamics of the interview in a moment.

Just a short additional comment about the way of getting in touch with the interviewee: When Agnieszka wrote that Natalia was the one of few (6) persons who established contact with me this way (i.e., by responding to a letter), I was reminded of research situations of students of mine in which interviewees were recruited via newspaper ads, that means, they responded to advertisements. [During the last years quite a few also got in touch with possible interviewees via Facebook.] Of course, this is somewhat different from responding to a letter - a letter of a social scientist who "I" do not know. The letter is addressed specifically to "me," whereas an ad ("I am looking for former inhabitants of children's homes") turns to an anonymous audience, but both situations have something in common - it is not too difficult to avoid a response (Natalia was one of the few who responded to the letter). Natalia's response reveals an interest in participating in this research. Thinking of the research of students of mine, I had the idea (when reading the researcher's comment and before getting familiar with the transcription) that she might either have a special need for someone who she could talk to (e.g., because she is lonely and there is no one to turn to), or that she might have a special message or commitment and wants to make a contribution to research. As Agnieszka writes: the narrator herself contacted the Institute by telephone and volunteered for the interview - she wanted to show the fate of a person brought up in a children's home.

\section{Some Remarks on the Researcher's Style of Interviewing}

I think it is rather trivial to observe that the request at the beginning of the interview - "Natalia I would like to, so to start this story, that you'd say a few words about your family, about your origins" (see: "Transcript of Biographical Interview with Natalia" in this issue of QSR, p. 117, lines 1-2) - is not a formulation which is likely to elicit an elaborated and spontaneous presentation. After a short sequence of clarification, Natalia talks rather shortly about her family and ends quite soon: "[w]ell, what am I to say now?" (p. 117, line 15) - a coda of perplexity. The observation about the lack of a "generative force" of the opening request also applies to questions in many guided interviews regardless of the specific research topic. Such interviews often contain a series of open questions leading to very short responses or leaving it open ("a few words about your family") for the interviewee if she or he is expected to narrate, argue, or describe something. This is a very general observation on many interviews; it also partially applies to the interview with Natalia.
But, I would like to focus on something which is more interesting with regard to the specific topic of the interview and which reveals something of the researcher's attitude towards her interaction partner. The interviewer is extraordinarily circumspect, polite, and conscious of the fact that she might violate borders which should not be violated. This is already visible in the very beginning of the interview when she addresses Natalia, the interviewee: "Natalia I would like to, so to start this story, that you'd just say a few words about your family, about your origins" (p. 117, lines 1-2). When Natalia asks for clarification and orientation: "[f]rom the very beginning?" (p. 117, line 3), Agnieszka specifies: “[m]mhm. I mean about your parents, well about..." (p. 117, line 4). Natalia hesitates and marks this topic as problematic: “[a]bout my parents... well this will be a little difficult but sometimes/" (p. 117, line 5), whereupon the interviewer steps back: "[i]f not about than/just about childhood" (p. 117, line 6), that means she expresses a concern that talking about one's biographical origin might be unpleasant and should not be forced upon the other person. In this phase of negotiation, she shows her willingness to reduce the topic. But, how can one talk about one's childhood by leaving out one's parents? The researcher's anxiety that her kind of asking questions might be obtrusive and risky for the interviewee is visible at different points, for example, when she, more or less, apologizes and announces her wish "to shut these family threads" of the difficult topic of the fate of her siblings (p. 129, lines 10-11), or when she offers to take a break in situations when the interviewee loses her composure.

Agnieszka made an interesting remark in her introductory commentary about this interview: [t]he interview with Natalia was the most difficult biographical interview I have ever conducted due to the narrator's very strong emotions and symptoms of suffering. These emotions were evoked by the stories of sibling and parents; (the) narrator's weeping appeared frequently when she talked about her younger brother. So, I decided to first close up the threads concerning the siblings' fates, after the story about the childhood, and only then continue the story of her own life.

I find this remark sums up very well the interview strategy which emerged in this situation. In the first part of the interview, Natalia gets intensely drawn into painful memories and assessments of her siblings (and of their life together), she often loses her composure. The interviewer has a keen sense of this momentum of pain, expresses her sympathy, for example, when she suggests taking a break several times, or repeatedly announces her wish "to close these threads." She picks up the tone of the interviewee when talking about her lost siblings, something like a joint construction of the image of siblings who are essentially unlike "me" emerges. It is interesting that these announcements "to close these threads" also serve as apologies for continuing to explore and deepen this thematic line for a while. The researcher and the interviewee jointly focus on the fates of Natalia's siblings - their history of multiple forms of deviance, their moral character and demoralization, educational non-achievements, broken relationships and whereabouts - before focusing on what Agnieszka calls "the story of her own life." This is marked by a clear announcement introducing a major new part of the interview: "[w]ell Natalia we are coming back to you/" (p. 137, line 15), in which she turns to a special phase in Natalia's life - her five years in the children's home. 
The prior narrative and argumentative sequences had also dealt with Natalia's life - "her own life" in the context of her family of origin and her attempts to gain autonomy. We learn a lot about:

- the history of her family trajectory due to her parents alcoholism

- her early and untimely obligations of having to take care for her younger siblings,

- the temporary dissolution of the family after her father's imprisonment and her mother's loss of control, which leads to a sharp intervention of control agencies (initiated by her maternal grandmother)

- her experience of a new life with her paternal grandmother (both grandmothers provide some background stability),

- her shock when returning home to the reunited family after her father's release from prison,

- her suicide attempt as a desperate action scheme of escape,

- her being committed to the children's home and her regaining control over her life in the new surroundings, which she experiences as a real "home" ("[a]nd at that, from the moment I came to this children's home I pulled myself together..." [p. 122, lines 28-29]),

- her biographical action schemes in the educational and occupational spheres after leaving the children's home, and

- the early development of a stable love relationship with her future husband and becoming part of his family.
When the interviewer directs the interviewee's attention to "the story of her own life," she has in mind Natalia's life outside of her family. The researcher provides an outside order - the "threads" of the fates of Natalia's siblings versus her very own life, but one could also ask if this imposed order runs the risk to obscure the inner form or gestalt of her life which has been deeply intertwined with her family and her siblings (till the present day). I think that the interviewer tries to make a sensible decision in the light of the development of the interview when she starts to explore the thematic potential of the fates of Natalia's siblings (it is something like "let's get over this unpleasant topic together as quickly as possible, even though it takes some time") before turning to the subject matter, which is of major interest to her research: the life in the children's home and its consequences. I think, though, that the development of Natalia's structural processes of her life course (Schütze 1981), her own history within and outside of her family of origin, and her history of gaining autonomy and self-confidence would have become even more clearly visible in the narrative segments of a coherent autobiographical narrative interview. Later on in the interview, a spontaneous narrative about the emergence of autonomy after leaving the children's home evolves, when the interviewer asks her, "[h]ow did the matter of your becoming independent, later, how did it look like, this entering the adult/" (p. 142, lines 3-4).

Despite the fact that the researcher tries to avoid the format of a narrative interview, Natalia turns to offthe-cuff story telling about personal experiences herself and is thereby exposed to narrative constraints. This happens already quite early in the interview. I would like to focus on some interesting formal fea- tures of Natalia's introductory narrative, which are of substantive interest for the analysis as well.

\section{Some Features of the Introductory Narrative}

As already mentioned, there is a short statement of the interviewee at the beginning in which she introduces her family in response to the researcher's question: the points of origin of her parents, their meeting each other (the interviewee is insecure in this regard and assumes that it has to do with her father's deployment as a soldier in Lodz, her mother's birth place), their moving to Lodz together in 1979 or 1980, her siblings (which she lists according to their age and with regard to her position in the sequence; she also remarks in the end, "I got the sequence wrong, anyway there are six of us, of which one child uhm... died at the age of two in 1983 uhm... Well, what am I to say now?" [p. 117, lines 13-15]). [I will return to the death of a sibling, which she refers to here, somewhat later.]

After this short initial presentation of her family, the interviewer asks another question: "[m]aybe you will say just a little about your story, just about your childhood. That is, when were you born, where, what did your childhood look like?" (p. 117, lines 16-18). The transcription does not reveal if the pronunciation of "your story" already stresses "your" in contrast to "your family's" story. In any case, a spontaneous introductory autobiographical narrative unfolds (from p. 117, line 19 to p. 125, line 15) which encompasses the time between Natalia's birth in 1975 and her admission to the children's home when she is fourteen. [She stays in this home until she is 19 years old and moves into her own flat afterwards.] The story ends with a coda: "I don't know what else I am to say..." (p. 125, line 15). Afterwards, the interview continues with a long sequence of questions and answers which are divided into distinct parts. [One part on "shutting these family threads" (p. 129, line 10 to p. 137, line 14) was already discussed in the last section.]

When I turn to Natalia's introductory narrative, I will not go into details with regard to the unfolding of experiences and events, I assume that readers have the chance to read the transcription themselves. I would like to focus on two formal features of this narrative which help us to gain a deeper understanding of Natalia's trajectory of suffering and her attempts to make sense of and evaluate her life: (a) the features of a difficult background construction ${ }^{6}$ and

${ }^{6}$ The phenomenon of background construction as a feature of spontaneous narratives of self-lived experiences has been anaspontaneous narratives of self-lived experiences has been ana$235 ; 1992: 352-353 ; 1995 ; 2008 b: 27-33)$. It has turned out to be a central symptomatic textual indicator of such narratives for the discovery and deeper understanding of trajectories of suffering and losing control. As Schütze (2008b:27-28) writes, "[e]specially background constructions...demonstrate that extempore auto-
biographical narrations express even personal experiences that the narrator tended to fade out of her or his awareness since they were so difficult, hurting, or shameful. Background constructions are self-corrections of the narrator regarding the course of her or his narrative rendering at points of its implausibility. They are quite often initiated by the narrator her- or himself, when during her or his permanent self-monitoring she or he realizes that the course of presentation becomes questionable, ny, etc. Then the narrator is driven by the narrative constrain of going into details. The narrator understands that something is missing between the rendering of event $\mathrm{A}$ and a following rendering of event $B . .$. Background constructions react to chaotic phases in the extempore recollection of personal experiences; in a certain sense their repair mechanism should bring back order into the chaotic phases of narrative rendering and the connected recollections of sedimented biographical experiences. But they normally accomplish this without any polishing, refurbishing if and when they can fully unfold and carry through their repair job. Insofar, the insertion of background constructions is the diametrical contrast to fading out, rationalization, and legitimizing, on the level of the dominant line of narrative rendering. The order that is introduced by the fully accomplished background construction is much more complicated than the original order of the narrative rendering. Therefore, background construction are an important means for creative biographical work." 
(b) an extended pre-coda commentary (Schütze 1981:183).

(a) The Background Construction (p. 118, line 11 to p. 120, line 10)

A new narrative segment starts in p. 118, line 3 when the interviewee mentions, "[m]y dad... uhm... in 88 or 89 went to prison for two years because..." After providing an account for her father's conviction for illegal trading of alcohol (an explanatory and partially exonerating commentary: "due to that I mean I don't want to justify anybody here but" [p. 118, line 4]), she repeats the sentence about her father's imprisonment and continues with a statement which marks a dramatic deterioration in the family trajectory: "[a]nd then it all began, it all began to fall apart" (p. 118, lines 10-11)

At this point (p. 118, line 11), she corrects herself and introduces a background construction:

although earlier there were such situations, that if perhaps social care had been more often interested uhm, in depth and probably earlier, everybody would have ended up in children's home and this may have been better for us. Because of all the family, to be honest, that's the only real home I have ((cries))... (p. 118, lines 11-14)

The interviewer empathetically offers to take a break and hands tissues to the interviewee. After regaining her composure, Natalia goes on by describing how her mother had neglected them ("somehow my mother didn't pay attention to look after us so that we had clean neat things" [p. 118, lines 18-19]), which created some embarrassment in her school environment, ${ }^{7}$ even though the interviewee emphasizes that she avoided outright stigmatization by her own effort: "and one always made up for this with one's character and I don't know, somehow it..... it was okay" (p. 118, lines 24-25). She mentions the disadvantages in school which they experienced due to their home - "[b]ut it never was so that we had time to learn super-extra so that we would be among the school class leaders" (p. 118, lines 25-26); "[s]ometimes there was no lunch" (p. 118, line 26-27) - but she also tries to balance this picture by taking into account: "although my mother cooked quite well... when everything was okay it was okay" (p. 118, line 28). At this point, she picks up the commentary again, which had appeared quite early in the background construction - "[h]owever/ well I just started to talk about my/ about my brothers and sisters, so well... only just me... as the only one of these six" (p. 118, lines 2830) - before she corrects herself again ("five actually cause one child we lost" [p. 118, line 30]) and is drawn into a background construction of second degree or second order (Schütze 1987; 2008b:32-33; Riemann and Schütze 1991:346-347), that means, an (additional) background construction within a comprehensive or overriding background construction (of first order), which I will focus on shortly: the dramatic story of having to witness the death of her two-year-old sister Gosia (p. 118, line 30 to p. 119, line 15). After ending this background construction of second degree (on p. 119, line 15) and answering a few short questions of the researcher

${ }^{7}$ The topic of the youthful experience of shame and the undermining of self-confidence because of having to wear shabby clothes already appeard in the first (classical) written Germa autobiography Anton Reiser by Karl Philipp Moritz (1977 also emerges in different autobiographica narrative interviews that come to my mind. (on the year of Gosia's death and her age when she died), she loses the thread (p. 119, line 21): "[w]ell, well and... I don't know what I started to say I lost track." The researcher directs her attention to her commentary on her siblings ("[y]ou started talking about your siblings" [p. 119, line 22]), and Natalia picks up this line again: "[s]o, well, among the siblings actually just I, I do live, say, not for today, but just so normally as a normal person" (p. 119, lines 23-24). Her commentary is mainly an elaboration of a contrast-set between her "normalcy" and the depressing fate and demoralization of her siblings but also (in the end) an affirmation of her ties with her family (p. 120, lines 8-10):

[a]lthough I would not want to identify with my/ that is, I will never renounce my family and I will always help anyone if there is such a need. But I can't live like them. I just cannot and that is, it seems to me, that is the reason why I found myself in the children's home. Because uhm...

I assume that the background construction ends at this point (p. 120, line 10), and the narrator returns to the main story line - the time when her father was imprisoned and her mother lost total control: "like my dad... in the 80s uhm... 90, just a moment, 89 it was I guess when he was sent to prison, so my mom completely lost it, uhm... lost probably... a sense that she is a mother" (p. 120, lines 10-12).

My discussion of the formal features of this extended background construction might have seemed like a sterile finger exercise but the point is, that by looking closely at these features, we learn a lot about Natalia's trajectory of suffering and her difficulties in remembering painful experiences which she had "faded out" of her awareness (Schütze 1992). When she mentions that "it all began to fall apart" (p. 118, line 11) during her father's imprisonment, she corrects herself and reveals some more of the turmoil, neglect, and shame, for example, the shame because of having to wear shabby clothes, which she and her siblings had experienced even before her father was sent to jail. Even though she had shortly referred to "alcohol binges" (p. 117, line 34) and their increase before ("and it got worse and worse" [p. 118, lines 2-3]), she had not gone into details.

When Natalia starts her background construction, she alludes to dramatic situations in her family, which public welfare authorities should have responded to. [She develops a global theory at this point: If the siblings had been placed in children's homes, their lives would not have deteriorated. She was the only one who had been spared this fate.] At the beginning of the background construction, she does not mention specific situations yet, but an especially dramatic event ("Gosia's death") is introduced when she has to correct herself again - this time with regard to the number of siblings who are still alive. This is the first situation in her narrative which is told in a detailed way - the situation of having to witness her little sister's death, without being able to do anything for her, while her parents had gone out and had locked them up in their home. This experience must have been traumatizing for her (as an eight-year-old girl) and her somewhat older and somewhat younger brothers. The sequential and comparative analysis of spontaneous narratives of personal experiences has led to the insight that such background constructions of second order contain especially troubling or painful 
memories. Even though the first order background construction had already been introduced as a corrective device in order to rectify a presentation, which had been too "smooth," it is only by way of another self-correction - that means, the insertion of a background construction of second order - that especially troubling experiences "squeeze" into her story. Gosia's death appears to belong to the most painful experiences of Natalia's life - an experience which somehow resists a straightforward narrative recapitulation, but unintentionally comes up in her story nevertheless.

At the beginning of the story of Gosia's death, we find the commentary “although I just don't want to blame anybody" [p. 118, line 30]. And the story ends with another commentary:

[s]o it seems to me that if, if anybody had had an interest in this child earlier, she wouldn't have died. Cause this meningitis purulent uhm... certainly had been developing much, much earlier, and in my opinion, this child was neglected. I can state that now, though at the time I was a little kid and well and besides, it's difficult to judge uhm... parents, isn't it?" (p. 119, lines 11-15)

These commentaries show Natalia's moral problems in ascribing responsibility for her sister's death in an unambiguous way. She sees how her parents were implicated in the sick child's "neglect," but she is still hesitant in explicitly condemning them. [She had made peace with her father before his death and has also somehow made peace with her mother, too, who she regards as a good grandmother for her daughter.] When she uses the passive form ("this child was neglected"), also others ("social care") appear implicated. She seems to assume that public authorities should have stepped in in time in order to save a life - and to prevent the long-term misery of her siblings, too. Natalia's reluctance, as far as the outright condemnation of others is concerned, also gleams in he evaluation of her siblings' character (in many parts of the interview). Even though she talks harshly about their present situation and states of mind, she has many (often loving) memories of them as children and youths, and she has a clear notion of wasted opportunities.

(b) The Extended Pre-Coda Commentary (p. 123, line 23 to p. 125, line 15)

The communicative scheme of narration stays dominant in Natalia's introductory narrative but a number of theoretical and evaluative commentaries are also embedded within - commentaries which have to be understood as activities in the scheme of argumentation (Riemann 1987; Schütze 1987; 2008a; 2008b). I have already alluded to some of these (subordinated) commentaries in my discussion of the background construction. In many parts of her narrative, Natalia is provoked to argue, for example, when she mentions how her paternal grandmother had often unfairly criticized her ("that I am like my mother" [p. 121, line 16]) when she lived with her during her father's imprisonment. The interviewee's present response to this criticism of many years ago - "I don't think that... only my mother is to blame....." (p. 121, lines 17-18), et cetera - reveals something of Natalia's entanglement in her family and her difficulties of making sense of and coming to terms with what has happened.
Fritz Schütze (1987:183) has discussed one type of commentary in a detailed way, the one which appears at the end of off-the-cuff storytelling of personal experiences. He refers to it as "pre-coda commentary" - an extended commentary in which narrators try to arrive at general evaluations of their experiences and of themselves but often find this difficult. Painful issues come up. Oftentimes, they develop conflicting propositions, give reasons, and try to back them up with evidence without discovering an easy way out of this spiraling discussion with themselves.

Something like this can be observed in Natalia's introductory narrative, too. There is one extended commentary which appears before the coda (p. 125, line 15) of Natalia's introductory narrative. It starts after her evaluation of how the order and support which she had experienced in the children's home had positively affected her life in the long run (p. 123, lines 23-25):

[a]nd the fact that, well, these five years at this children's home really helped me a lot. Because - in retrospect I now see that, I don't know, I don't want to judge anyone here somehow super-positively, but I think I am a good mother...

She goes on to depict her qualities of a mother and the trust in her home - in contrast to her own plight as a girl (p. 123, lines 29-32):

I didn't have that, didn't have such understanding, I had no such love. This children's home gave me the direction, the fact that I completed a lot of different schools, and that in the end I am a fairly educated person, maybe not so super-extra, but I did the ba/ Bachelor degree.
She says that “I regret that I couldn't do anything for my family, my brothers and sisters so that they would be in the sa/ the same situation as $\mathrm{me}^{\prime \prime}$ (p. 123, lines 34-35) and continues to portray the conditions and social milieu ("neighborhood," etc.) in which her brothers grew up, so that they got in trouble and ended up in prison. It is interesting to see that the way in which she talks about her brothers as children has a tender quality ("a sensitive kid" [p. 124, line 15]). She invokes a we-community of her and her two brothers (who are somewhat older and somewhat younger than her): "we had such such, such children dreams actually" (p. 124, line 20). When remembering an especially moving story, she loses her composure (p. 124, lines 21-26):

we walked the streets when we saw there were such... ((cries, long pause))... these stray dogs. Poor, hungry ((cries)) we took them home. And I don't know, maybe we found five such dogs, we fed them we gave them water. And once we, once we just - we told each other so, that when we grow up ((cries)) we will open a shelter for these poor, homeless dogs ((cries))...

This episode serves her to emphasize the essential moral qualities of her brothers during their childhood and their potential, which could have unfolded under different circumstances. She contrasts her younger brother's early qualities with his present state of mind ("now he doesn't think rationally" [p. 124, line 30]) and his situation - his being drawn deeper and deeper into "a criminal world" (p. 124, line 32) (also because of his imprisonments). In lamenting their fate, she reveals that she has developed a kind of critical milieu theory with regard to her brothers' fate: If her brothers had been given the opportunities, which she had 
benefited from, they wouldn't have ended where they are now. ${ }^{8}$

At the same time, she affirms the continuing bond between herself and her siblings (p. 125, lines 6-9):

[a]nd - I still keep in touch with all them, although I don't - I don't go to these prisons because, well, I have my life, I have a grandma who is already/ who according to/ to whom I'm responsible to help, cause when I needed this help she helped me too.

That means, she invokes a sense of reciprocity in her relationship with her grandmother who needs her support now. It is interesting to see that she also draws a line with regard to her brothers and justifies her decision to keep some distance (p. 125, lines 9-11): "so I don't go somehow, so terribly often over to these prisons simply because I'd have to spend every free weekend to go somewhere all over Poland and visit brothers who really, well, they made a choice." This justification for her attempt to keep a distance - "they made a choice" - contrasts with her prior theorizing which stresses their downward drift or trajectories of suffering due to the fact that they had been robbed of their chances.

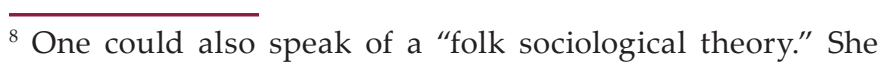
does not refer to "bad family genes" or other medical explanations in order to make sense of their fate, even though she uses the language of psychopathology to describe some of her siblings' present state of mind ("he doesn't think rationally, doesn't think normally" [p. 124, lines 30-31]). In a later part of the interview, she mentions "alcoholic genes" (p. 151, line 16), when talking of her maternal grandfather: "my mother's
father, such alcoholic genes, just so (((ironic laughter))) from father, such alcoholic genes, just so (((ironic laughter))) from
generation to generation" (p. 151, lines 18-19), but this kind of generation to generation" (p. 151, lines 18-19), but this kind of
theorising does not appear dominant in thinking about her family. She also has the conception of her family of origin as a "pathological family" (p. 117, line 23) and subsumes her own sense of loyalty under this psychiatric expert category: I once watched a film that the... children from such pathological families... will never say a bad word about their parents and love them so much" (p. 128, lines 16-17).
Right at the end of her introductory narrative, she draws a strong contrast-set between her brothers and herself by affirming their "choice" versus her own decision to strive for autonomy - a decision which led to suffering and loneliness (p. 125, lines 11-15):

I rebelled, it cost me a lot, because I don't know, perhaps only God knows how many nights I cried the whole night through... cause I felt rejected and when there is/ I don't know, whatever this grandma would be, whatever this father would be, one loves them and wants such uh... such acceptance from them so that... whatever, they would stick to us... I don't know what else I am to say...

This impressive sequence conveys both her affirmation of her individuation and striving for autonomy, and her keen sense of what she lost when her rebellion was regarded as an act of betrayal. Her words express a deep sadness about a lack of reciprocity in her relationship with her family of origin. ${ }^{9}$

This lack of reciprocity and her attempts to restore reciprocity are a recurring topic in the interview, for example, when she talks about her later conciliation with her father and the fact that he entrusted the organization of his funeral to her: "[a]nd in fact he loaded me with ((cries)) the duty of burying him, organizing the funeral" (p. 128, line 7). Even though she remembers quite clearly that her father and mother did not function as responsible parents ${ }^{9}$ She refers to painful experiences in this context on page 141,
lines 22-25 when she talks about events during holidays at home while she was in the children's home: "I had a choice to either/ simply spend them in company of drunk parents, with fights. And usually when my parents drank then I always had... I was always reproached that... that... What was I there for, that I'd moved out, that I didn't want be there an so on and so on." (during her childhood and youth), she insists on always having fulfilled her obligation (p. 128, lines 26-29): a moral basic position.

\section{Concluding Notes: Topics of an Analytical} Abstraction

The interview is a remarkable piece of data, which makes it possible to learn a lot about one person's particular fate and outlook on life. But beyond that, it is possible to arrive at first general insights which need to be further differentiated by way of contrastive comparative analyses (Glaser and Strauss 1967).

I have tried to show in the preceding chapter how a careful consideration of formal features of the text can help us to arrive at a deeper understanding of "what is the case." Such an outlook belongs to the step of a formal-substantive structural description, which always precedes an analytical abstraction (Schütze 2008a; 2008b). I could only demonstrate this step by focusing on certain phenomena. It is always important to engage in a careful sequential structural description of the whole data before doing an analytical abstraction. I would just like to allude to some topics which should be considered in an analytical abstraction.

Despite the fact that Agnieszka did not use the format of an autobiographical narrative interview, it is possible to reconstruct the interplay of a family trajectory and individual biographies, especially, the biography of Natalia, the interviewee, who freely tells about what has happened to her and tries to make sense of it. [What we learn about her parents' and siblings' biographies is just based on her testimony and outlook.] The structural processes of her own life course become clearly visible: the expectation patterns, which she is exposed to as the oldest daughter of a family who is often in deep trouble because of her parents' alcohol addiction - her prematurely becoming the caretaker of her siblings; her trajectory of suffering in the family turmoil (remember her having to witness her little sister's death); a more quiet phase in her life during her father's imprisonment when she lives with her paternal grandmother and somehow learns to make comparisons and to distance herself from the chaos of her family of origin; after her return: her biographical action schemes of escape when she tries to take her life ${ }^{10}$ and (after she is discovered and saved) to choose the life in a children's home over the life with her family; her learning to appreciate the quality and care of a milieu which she regards as "home," while also suffering from the parents' reproaches of her lack of loyalty; the emergence of successful biographical action schemes (in the spheres of education and occupational life) after her release from the children's home, and the early bond with her future husband with whom she has a daughter and has built a stable home.

It is also possible to detect a disposition of vulnerability which derives from (a) her early sense of communion with her brothers and her very early (untimely) entanglement in family duties when she has to take care of her younger siblings and (b) her decision to retreat from the family when she attempts to take her life and (when this suicide

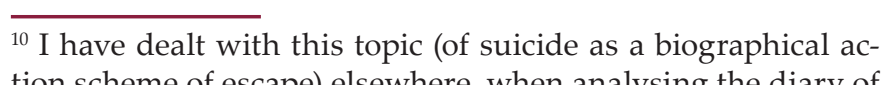
tion scheme of escape) elsewhere, when analysing the diary of a young man who took his life (Riemann 2007). 
attempt fails) to live outside of her family. She still feels ashamed of what she did, when she tried to commit suicide, and she keeps this a secret from her daughter - something which contrasts with her commitment to the value of openness and honesty in family relationships. It would be helpful for her if she developed a different attitude to this shameful secret and could accept it as an act of rebellion and as an - admittedly self-destructive - biographical action scheme. ${ }^{11}$ Her retreat from the family does not diminish her strong bond with her siblings (as is visible in her unsuccessful attempt to accomplish her sister's admission to her children's home when she takes refuge with her), but she feels that there is a lasting gap between them because of this. She feels marginalized among her siblings but also does not want to belong to them (as a category of people who are unlike her). The tensions in her autobiographical theorizing, because of the complexity and biographical costs of her rebellion and retreat from her family, can be observed throughout the interview (cf., the end of the pre-coda commentary). At the same time, she evaluates this retreat positively because it created the condition for gaining autonomy and acquiring a sense of direction in her life.

Natalia's theorizing in the interview is dominated by theories of global evaluation (Schütze 1987:183185) - attempts to make sense of sad and puzzling events in her family, to deal with the moral character of her next-of-relations, to assess the development and quality of relationships (e.g., the con"Such a process of reevaluation and doing biographical work (Betts et al. 2008) could be fostered in a relationship with a proessional counselor. Autobiographical narration would be an important element in such a process. ciliation with her father), and to compare her fate with the fates of her siblings. The interview is also an occasion for her to relieve herself and to reflect upon painful experiences, it goes far beyond what she had announced when contacting the university (according to Agnieszka): the narrator herself contacted the Institute by telephone and volunteered for the interview - she wanted to show the fate of a person brought up in a children's home.

Natalia does not romanticize the life in her children's home or in such residential institutions in general (she is also aware that such homes did not help her siblings during their father's imprisonment), but she describes and evaluates the features of this particular milieu and its biographical significance for herself very positively (p. 138, line 17 to $p$. 140, line 14). Her analytical description focuses on (what she experiences as) the order of everyday life, duties which children and youths had to fulfill (e.g., having to take care of younger children), the trust between them and members of the staff as "true caregivers" (p. 138, line 18), their being invited to staff members' homes (and thereby, being exposed to another "normalcy"), the solidarity with a severely impaired child as a matter of course, etc. ${ }^{12}$ It is also interesting to discover how she makes use of informal advice given to her by a staff member in order to find her way in the outside world: "to best assess uhm... my future husband by judging the relationships at his home, and what relationships uhm... the father has uhm... with the... with the mother..

${ }^{12}$ I was wondering if the text contains references to the fact that Natalia entered the children's home in 1989, a phase of revolutionary change in Poland. In any case, living in the children's home also meant that her world became larger. She mentions the contact with Dutch people who visited the home and
stayed in touch by mail. ((laughter))" (p. 145, lines 18-20). That means that this staff member provides her with some orientation in a biographically significant situation when she has to figure out the trustworthiness of the man who she has fallen in love with. Natalia's analytical descriptions of the children's home and her casual references to the biographical marks which care-

\section{References}

Bartelt, Guillermo and Bärbel Treichel, (eds.). 2012. Don Decker's Apache Odyssey. Approaches to Autobiography, Narrative, and the Developing Self. Berlin: Frank \& Timme.

Betts, Sandra et al. 2008. "Biographical Counselling: an Introduction." European Studies on Inequalities and Social Cohesion 1/2:5-58.

Glaser, Barney and Anselm Strauss. 1967. The Discovery of Grounded Theory. Chicago: Aldine.

Kallmeyer, Werner and Fritz Schütze. 1977. "Zur Konstitution von Kommunikationsschemata der Sachverhaltsdarstellung." $\quad$ Pp. 159-274 in Gesprächsanalysen, IKP-Forschungsberichte. Reihe I, Vol. 65, edited by D. Wegner. Hamburg: Buske.

Kaźmierska, Kaja. 2002. “Narratives on World War II in Poland: When a life story is family history." The History of the Family 7(2):281-305.

Kaźmierska, Kaja. 2012. Biography and Memory. The Generational Experience of the Shoah Survivors. Boston: Academic Studies Press.

Miller, Robert and Graham Day, (eds.). 2012. The Evolution of European Identities. Biographical Approaches. Houndmills, Basingstoke: Palgrave Macmillan.

Moritz, Karl Philipp. 1977. Anton Reiser. Ein psychologischer Roman. Stuttgart: Reclam. (First edition: Berlin 1785). takers have left on her (like the one just mentioned) can be important data for professional discourse, and self-reflection on such institutions and the relationships with young clients - just like the detailed sequences about her suffering from her family's accusations that she betrayed them (which were also voiced during her stay in the children's home).

Riemann, Gerhard. 1987. Das Fremdwerden der eigenen Biographie. Narrative Interviews mit psychiatrischen Patienten. Munich: Fink.

Riemann, Gerhard. 2000. Die Arbeit in der sozialpädagogischen Familienberatung. Interaktionsprozesse in einem Handlungsfeld der sozialen Arbeit. Weinheim and Munich: Juventa.

Riemann, Gerhard, (ed.). 2003. Doing Biographical Research. Forum Qualitative Sozialforschung / Forum: Qualitative Social Research 4(3). Retrieved August 27, 2013 (www.qualitative-research.net/index.php/fqs/issue/ view/17).

Riemann, Gerhard. 2007. “Suizidalität als Prozess. Eine Re-Analyse des Tagebuchs von Wallace Baker in Ruth Shonle Cavans 'Suicide."” Zeitschrift für Qualitative Forschung 8(2):287-327. Retrieved August 27, 2013 (http:// nbn-resolving.de/urn:nbn:de:0168-ssoar-269962).

Riemann, Gerhard and Fritz Schütze. 1991. “Trajectory' as a Basic Theoretical Concept for Analyzing Suffering and Disorderly Social Processes." Pp. 333-357 in Social Organization and Social Process. Essays in Honor of Anselm Strauss, edited by D. R. Maines. Hawthorne, NY: Aldine de Gruyter.

Rosenthal, Gabriele, (ed.). 1997. Der Holocaust im Leben von drei Generationen. Familien von Überlebenden der Shoah und von Nazi-Tätern. Giessen: Psychosozial Verlag. 
Rosenthal, Gabriele. 2005. Interpretative Sozialforschung. Eine Einführung. Weinheim and Munich: Juventa.

Schröder-Wildhagen, Anja and Fritz Schütze. 2011. “How to deal with autobiographical narrative interviews in the Euroidentity Research Project." Sociologcial Review 60(1):41-91.

Schütze, Fritz. 1981. "Prozessstrukturen des Lebensablaufs." Pp. 67-156 in Biographie in handlungswissenschaftlicher Perspektive. Kolloquium am sozialwissenschaftlichen Forschungszentrum der Universität ErlangenNürnberg, edited by J. Matthes et al. Nuremberg: Verlag der Nürnberger Forschungsvereinigung.

Schütze, Fritz. 1987. Das narrative Interview in Interaktionsfeldstudien: Erzähltheoretische Grundlagen. Teil I: Merkmale von Alltagserzählungen und was wir mit ihrer Hilfe erkennen können. Hagen: Studienbrief der Fernuniversität.

Schütze, Fritz. 1992. “Pressure and Guilt: War Experiences of a Young German Soldier and their Biographical
Implications." International Sociology 7(2):87-208 (part I) and 7(3):347-367 (part II)

Schütze, Fritz. 1995. "Verlaufskurven des Erleiden als Forschungsgegenstand der interpretativen Soziologie." Pp. 116-157 in Erziehungswissenschaftliche Biographieforschung, edited by H. H. Krüger, W. Marotzki. Opladen: Leske + Budrich

Schütze, Fritz. 2008a. "Biography Analysis on the Empirical Base of Autobiographical Narratives: How to Analyse Autobiographical Narrative Interviews - Part I." European Studies on Inequalities and Social Cohesion 1/2:153-242. Retrieved August 27, 2013 (www.uni-magdeburg.de/zsm/projekt/biographical/1/B2.1.pdf)

Schütze, Fritz. 2008b. "Biography Analysis on the Empirical Base of Autobiographical Narratives: How to Analyse Autobiographical Narrative Interviews - Part II." European Studies on Inequalities and Social Cohesion 3/4:5-77. Retrieved August 27, 2013 (www.uni-magdeburg.de/zsm/projekt/biographical/1/B2.2.pdf ).

Riemann, Gerhard. 2014. “A Situation, a Narrative, and a Life History. The Case of Natalia." Qualitative Sociology Review 10(1):20-36. Retrieved Month, Year (http://www.qualitativesociologyreview.org/ENG/archive_eng.php). 